\title{
Site Suitability Analysis of Water Harvesting Structures Using Remote Sensing and GIS - A Case Study of Pisangan Watershed, Ajmer District, Rajasthan
}

\author{
Harish Chand Prasad, Parul Bhalla and Sarvesh Palria
}

Dept. of Remote Sensing and Geo-informatics

MDS University, Ajmer - 305009

\author{
harishchand2008@yahoo.com
}

\section{KEYWORDS:}

Water Harvesting Structures, Analytic hierarchy process model, Spatial Analyst Tool, Multi Criteria Analysis, Runoff Depth

\begin{abstract}
:
Rajasthan is a region with very limited water resources. Water is the most crucial for maintaining an environment and ecosystem conducive to sustaining all forms of life. The principle of watershed management is the proper management of all the precipitation by the way of collection, storage and efficient utilization of runoff water and to recharge the ground water. The present study aim's to identify suitable zones for water harvesting structures in Pisangan watershed of Ajmer district, Rajasthan by using Geographic Information System (GIS) and Multi Criteria Evaluation (MSE). Multi criteria evaluation is carried out in Geographic Information system to help the decision makers in determining suitable zones for water harvesting structures based on the physical characteristics of the watershed. Different layers which were taken into account for multi criteria evaluation are; Soil texture, slope, rainfall data (2000-2012), land use/cover, geomorphology, lithology, lineaments, drainage network. The soil conservation service model was used to estimate the runoff depth of the study area Analytical Hierarchy Processes (AHP) is used to find suitable water harvesting structures on the basis of rainfall. Produced suitability map will help in the selection of harvesting structures such as percolation tanks, storage tank, check dams and stop dams.
\end{abstract}

\section{Introduction}

The groundwater table in most parts of Rajasthan is steadily going down due to over-exploitation and inadequate natural recharge, resulting from frequent drought conditions in a region where the erratic annual rainfall is below $50-60 \mathrm{~cm}$ in most parts.

Water plays a vital role not only in fulfilling basic human need for life and health but in socio-economic development also. As the primary source of water is rainfall, so it becomes necessary for us to harvest it effectively we can maximize the storage and minimize the wastage of rain water.

In order to address the problem of the imbalance between abstraction and resources, it is necessary to augment the groundwater potential by artificial recharge of the depleted aquifers in a scientific and well-studied manner.

Generally, groundwater recharge requires applying water in surface and near-surface spreading basins, pits and trenches, using the unsaturated porous and permeable zones and the fracture planes to transport and store water. The hydrogeology of the unsaturated zones, particularly the vertical hydraulic conductivity of the land-cover materials, including the soils and the sub-soil sediments, frequency of fractures and fault zones, lineaments etc., play a critical role in transporting and storing the recharged water (Flint, 2002). Therefore, the study and evaluation of this zone and its geologic, tectonic, geomorphologic and land-cover attributes is important and necessary for selecting areas or sites for groundwater recharge.
Rain Water Harvesting and Conservation, is the activity of direct collection of rain water collected can be stored for direct use or can be re-charged into the Ground Water.

"Identification of suitable sites for water harvesting structures needs a large volume of multidisplinary data from various source for which the applications of modern remote sensing and geographic information system techniques have gained much attention in recent years". (Ramaswamy \& anbazhagan 1997).

"Each watershed has various physiographic characteristics of the study area such as geomorphology, geology, structures, landuse/landcover, soil \& drainage pattern integrated with the help of Remote sensing and GIS techniques. SCS-CN technique was used to generate rainfall runoff model, the developed rainfall-runoff model is used to understand the watershed and its runoff flow characteristics. The rainfall runoff result of the trend line shows that there where the Runoff potential is high or low. On the basis of interpretation Water harvesting sites are suggested" (Porchelvan et al., 2009).

Aggarwal et al., (2008) "study deals with the potential sites for construction of rain water harvesting structures in the Bakhar watershed of Mirzapur district, UP. It has been identified by using remote sensing and GIS technology. Various thematic maps such as land cover/ land use, geomorphology and lineaments etc. these layers along with geology and drainage were integrated using GIS techniques to derive suitable ware harvesting structures each theme was 
assigned a weightage depending upon an the ground water recharge".

Pisangan watershed is the part of Ajmer district out of 8 blocks. Pisangan Watershed Covering Geographical area of $1201 \mathrm{Sq} \mathrm{km}$ including major town and city. According to CGWB report (2008), the net annual ground water availability was $54.2009 \mathrm{mcm}$ but the demand of annual for all users are $96.6411 \mathrm{mcm}$ and demand is increasing day by day due to increasing population and tourists those who came from outside that why the watershed falls in the category of Over-Exploited Ajmer city falls in Pisangan Block with total population of 7, 98,454, Nasirabad with population of 50,804 and Peesangan town with population of 15,741 are major populated areas falls in the watershed area. Most of the water supply to the area is being supplied from Bisalpur dam. Annual rainfall of the district is $447.2 \mathrm{~mm}$ Almost $95 \%$ of the total annual rainfall is received during the southwest monsoon, Drought analysis based on agriculture criteria indicates that the district is prone to mild and normal type of droughts. Serve and very serve type of drought happen very rare and occurred three times during 1987, 2002 and 2009.There is no important river in the district Khari, Dai, Sarsuti or Saraswati, Sagarmati rivers are ephemeral \& flow only in response to precipitation. The Ana Sagar \& Puskhar are two natural lakes near the Ajmer City.

According to CGWB Report Ajmer, area around Ajmer, Nasirabad and Peesagan exhibit steep depletion of water level. At the annual rate of $2.74 \mathrm{~m} / \mathrm{yr}$. Mostly Rivers Dai, Swarswati and Sagarmati mainly response to the Precipitation, According to CGWB Pisangan Block belongs to over-exploitation category. Availability of water in near future is going to become a matter of grave concern as the population is increasing at a constant growth rate.

Using GIS and AHP, the present study endeavours to locate the site for water harvesting structures in Pisangan Watershed. The people practicing the unplanned manner to store the water this study also provides the Suggested sites for water structures in planned manner for the conservation and better utilization of water.

Materials and Method To meet the objectives for the study area, data from the both primary and secondary sources have been used. They include the following:

i. Landsat 8 images, band 3, 4, 5; Resolution - 30 meter

a. Kharif - 18 October 2013

b. Rabi - 06 January 2014.

ii. ASTER DEM, Resolution - 30 meter.

iii. Rainfall data of 12 years (2000-2012).

iv. Primary data has land cover/ land use, drainage, and slope.

v. Secondary data, which are lineaments, Geomorphology, Lithology and Soil.

The data so obtained were digitized and converted into digital format in ArcGIS 9.3 for the spatial analysis. AHP Model was applied on the selected criteria and suitable weightages were allocated. All the layers were then converted into raster format and spatial analyst tool was applied for finding out the suitable location for the Water Harvesting Structures.

\section{Description of the Study Area}

The Watershed area of Pisangan Watershed is 1201.61 sq kms and located between $\mathbf{2 3}^{\mathbf{0}} \mathbf{4 4} \mathbf{4 5}^{\prime \prime} \mathbf{N}$ to $23^{0} \mathbf{5 8} 30^{\prime \prime} \mathbf{N}$ latitude and $\mathbf{7 8}^{\mathbf{0}} \mathbf{3 5} \mathbf{4 5}$ " E to $\mathbf{7 8}^{\mathbf{0}} \mathbf{4 6}$ '15" E longitudes. The climate of the study area is semi-arid and very hot in summer and extremely cold in winter. The monsoon is of very short duration. The Aravali mountain range (one of the oldest in the world) in western India runs approximately $482 \mathrm{~km}$ from northeast to southwest across the State of Rajasthan. The study area has an average elevation of $312 \mathrm{~m}$ Pisangan Watershed is the part of Ajmer District and covers Ajmer City.

Ajmer district is spread over an area of 8,481 sq. kms and is bounded by Nagaur district to the north, Jaipur and Tonk to the east and Bhilwara district to the south and Pali district to the east. The Population of Ajmer District 2011 census is approximately 2, 58,491.The watershed is well connected by National Highway No-8 and State highways making all the important places of the district easily accessible.

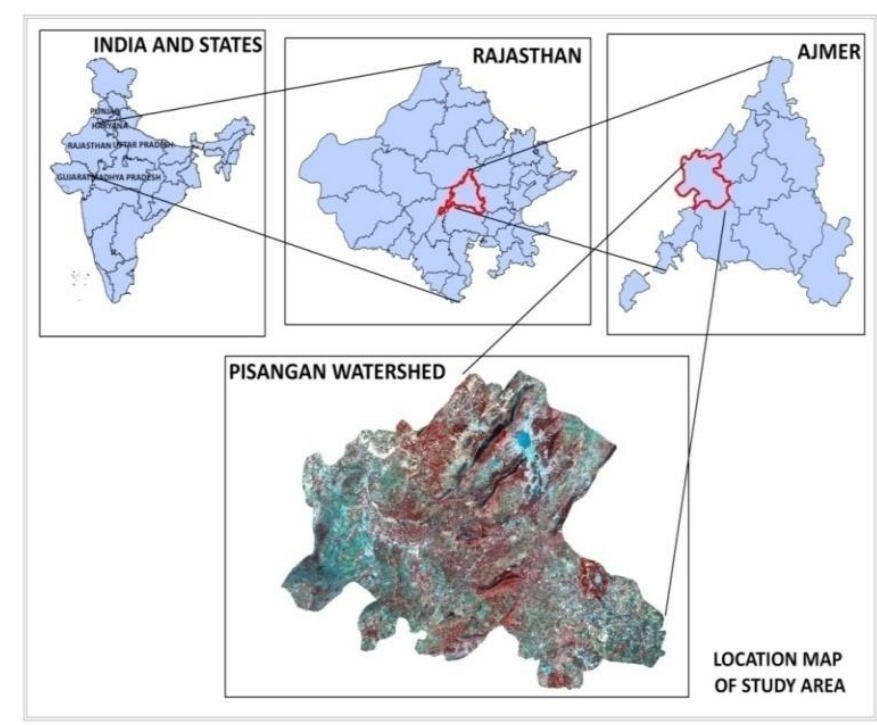

Figure 1 Study Area Location 


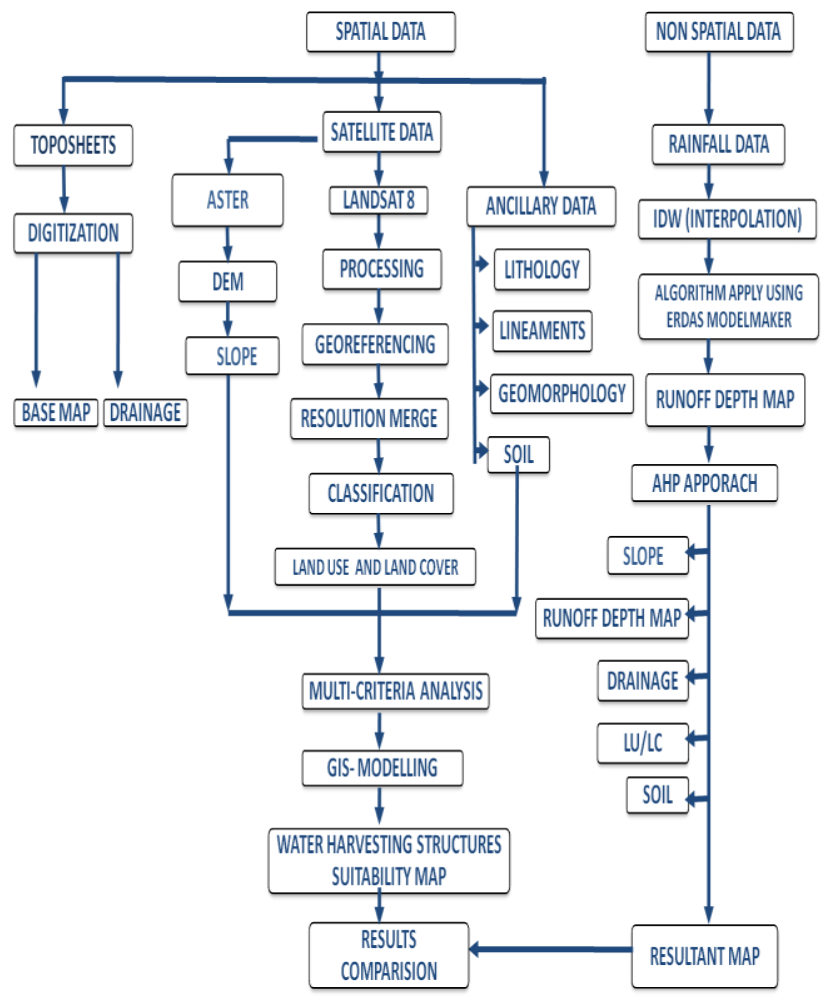

Figure 2 Conceptual Methodology

Preparation of thematic maps was a necessity for the study region, where digitization was used with the help of "ArcGIS" software and ERDAS is used for image processing, ERDAS model maker help for the runoff depth estimation where mathematical algorithms are applied and interpolation of rainfall is done using ArcGIS spatial analyst tool. Referring to previous studies, different criteria were chosen for determination of suitable area for water harvesting.

\section{Drainage}

Drainage network helps in delineation of watersheds and for suggesting various water harvesting structures and soil conservation measures. Drainage pattern is defined as the plan, which the individual stream courses collectively form. It refers to both spatial relations of individual streams and the overall pattern made by the individual drainage lines. The drainage pattern of Pisangan Watershed is formed by various tributaries and sub-tributaries of Swarswati River.

The Dendritic drainage pattern of Pisangan Watershed can be observed due many contributing streams. They develop where the channel follows the slope of the terrain. After drainage identification, orders are assigned to each tributaries and sub-tributaries respectively.

Drainage ordering represent the number of streams presents in each order defined i.e. $1,2,3,4,5$ and 6 stream orders. $2^{\text {nd }}$, $3^{\text {rd }}$ or $4^{\text {th }}$ order streams are suitable for Storage Tank and Percolation Tank. $4^{\text {th }}, 5$ th or $6^{\text {th }}$ order streams are suitable for Check Dams. $3^{\text {rd }}$ or $4^{\text {th }}$ order streams are suitable for Stop Dams. Stream length of each is taken out and analyzed.

\section{Lithology}

Lithology involves the study of landforms, structures, and the subsurface to understand the physical processes creating and modifying the earth's crust. Remote sensing is used as a tool to extract information about the land surface structure, composition, or subsurface, but is often combined with other data sources providing complementary measurements. In order to understand the Lithology of the study area, a general lithological map has been used mapped by RRSC, Jodhpur. Phylite, schist, slate, granite and gneissic are some of the Lithological units found in the study area. Gneiss are hard type material and Phyllite is type of metamorphic rock created from slate, It is primarily composed of quartz, sericitemica and chlorite. The schist is medium grade metamorphic rock, formed by mudstone/shale. Limestone is deeply absorbent because of its soft texture but the water dissolves the stone overtime runoff is moderate. Sandstone absorbs water because it is porous. This means that it has holes in.

The lithology units present in watershed having moderate to high rain runoff potential which are being used to conserve water by making scientific water harvesting structures with proper management. Lithology plays important role to recharge the ground water level. The total Lithological unit area is $1425.77 \mathrm{sq} \mathrm{km}$.

\section{Geomorphology}

The Geomorphological units available in the study area of Pisangan Watershed. Denudation hills, Structural hills, Pediments and Pediplains are some of the Geomorphological units found in the study area. The total area covered by the different landforms is $1438.03 \mathrm{Sq} \mathrm{km}$. In Ajmer district land forms have been classified on the basis of genetic factor and the geomorphic processes involved.

\section{DEM and Slope}

Digital Elevation Model is derived from ASTER Data. The Digital Elevation Model of Pisangan Watershed shows the areas elevation (height) at a class of 352-428 m, 428-475 m, $475-545 \mathrm{~m}, 545-657 \mathrm{~m}$ and $657-888$ respectively.

Watershed average slope offers information about the watershed topography. It is considered an independent variable. The average slope of a watershed influences radically the value of the time of concentration and, directly, the runoff generated by a rainfall.

Slope Map, is created with the help of Digital Elevation Model using ArcGIS-9.3 software. DEM is the basic input for generation of Slope map.

\section{Soil}

One of the most important features of soil, from the standpoint of its water holding capacity is variation in porosity with depth. Porosity is a measure of the open space 
within some soil or rock and it is function of the sizes of particles and the way they are arranged .Texture indicates the relative content of particles of various sizes, such as sand, silt and clay in the soil. Soil texture is an important soil characteristic that will be taking into consideration of suggesting water harvesting structures .The study area has been having different types of soil texture as fine loamy, coarse loamy, loamy skeletal, clay loam, and sandy loamy and rock outcrops.

\section{Lineaments}

Lineament in this study is defined as a map able, linear feature of a surface, whose parts are aligned in a rectilinear or slightly curvilinear relationship and which differ from the pattern of adjacent features and presumably reflect some subsurface phenomenon. The definition is chosen because it is the most practical definition in the context of remote sensing image interpretation. (Gupta, 1991). The buffer map is generated for lineament because it is the best geological unit which helps to collect the water and where the water is store at High capacity.

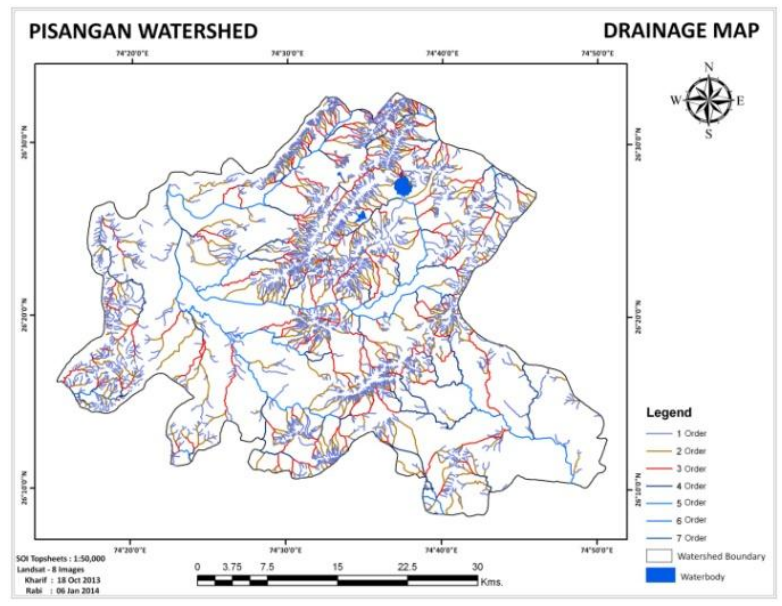

Figure 3 Drainage and Water body Map

\section{RUNOFF DEPTH ALGORITHMS Rainfall Data Interpolation}

Study area has only 7 rainfall gauging stations. A dense network is required to estimate accurately spatial distribution of a given area. Therefore 19 stations in Ajmer district are used for interpolation on the entire district and then interpolated rainfall map of the study area was clipped. Figure shows the location and distribution of the rain gauge stations of the study area.

Interpolation was used to estimate rainfall for the areas not having rainfall point measurements. The interpolation has been done in ArcGIS 9.3 using Inverse Distance Weight (IDW). Inverse distance weighted (IDW) interpolation determines, cell values using a linearly weighted combination of a set of sample points. The weight is a function of inverse distance (ArcGIS 9.3). The interpolated raster map shows variation in average annual rainfall. In the north and south eastern part of the study area having high rainfall.

\section{Rainfall Runoff Modelling}

Rain water harvesting is a hydrological intervention which can best be depicted through hydrological models that are able to show directions of flow, runoff and run on area and identify locations for impounding structures.

Runoff modeling is relationships for the basin are considered using the SCS curve number method. In undertaking hydrological modeling using remote sensing data in GIS environment the SCS curve runoff model is largely suitable due to its reliance on land cover parameters which can be extracted from remote sensing (Senay et al., 2004).

Runoff curve number equation estimates total runoff from total rainfall and this relationship excludes time as a variable and rainfall intensity. Its stability is ensured by the fact that runoff depth $(\mathrm{Q})$ is bounded between the maximum rainfall depth $(\mathrm{P})$. This implies that as rainfall amount increase the actual retention (P-Q), approaches a constant value; the maximum potential retention (USDA, 2004)

The runoff estimation related runoff $(\mathrm{Q})$ to precipitation $(\mathrm{P})$ and the curve number $(\mathrm{CN})$ which is in turn related to storage $(\mathrm{S}) . \mathrm{CN}$ is based on the following parameters; hydrologic soil group, land use and treatment classes, hydrologic surface conditions.

Equation 1 known as the runoff curve number gives the relationship between the parameters described below.

$\boldsymbol{Q}=\frac{(\boldsymbol{P}-\boldsymbol{I a}) \mathbf{2}}{(\boldsymbol{P}-\boldsymbol{I} \boldsymbol{a})+\boldsymbol{S}}$

\section{Where;}

$\mathrm{Q}=\operatorname{runoff}$ depth $(\mathrm{mm})$

$\mathrm{P}=$ rainfall $(\mathrm{mm})$

$\mathrm{S}=$ potential maximum retention after runoff starts $(\mathrm{mm})$

Ia = initial abstraction $(\mathrm{mm})$

Initial abstraction consists mainly of interception, infiltration during early parts of the storm, and surface depression storage. Its determination is not easy due to the variability of infiltration during the early part of the storm since it depends on conditions of the watershed at the start of a storm such as the land cover, surface conditions and rainfall intensity; thus it is assumed to be a function of the maximum potential retention. (USDA, 2004)

\section{$I a=0.2 S$}

Potential maximum retention $(\mathrm{S})$ can be calculated by the Curve Number as below 


$$
S=\frac{25400}{C N}-254
$$

The soil conservation service (SCS) model depends on the runoff Curve Number (CN). Curved Number is estimated via the effect of soil and land cover on the rainfall runoff processes. The range of the Curve Number $(\mathrm{CN})$ is between 1 (100\% rainfall infiltration) and 100 , lower values of the Curve Number indicate lower runoff, while higher values of Curve Number refer to higher values of runoff.

\section{Evaluating Curve Number}

Curve number is used to characterize the runoff properties for a certain soil and land cover/ land use. The soil conservation service runoff equation uses the curve number value as input parameter. Curve Number is evaluating for the study area on pixel basis using the land cover/land use and soil map that are reclassified to hydrologic conditions and hydrologic soil group (Table1 ).Infiltration depends on the soil property which effects the relation between rainfall and runoff. The soil conservation service model divides all soils into four Hydrologic Soil groups according to the united states geology survey (USGS) land use and land cover classification system (A, B, C and D). The classification of soil to hydrologic soil group depends on infiltration rates and the soil texture composition. Table defines the Hydrologic Soil Groups, based on the USGS classification system. Only classed A, B and D were found in the study area.

\begin{tabular}{|c|l|c|}
\hline Soil Group & \multicolumn{1}{|c|}{ Runoff Description } & Soil Texture \\
\hline A & Low runoff potential because of high infiltration rates & Sand, loamy sand and sandy loam \\
\hline B & $\begin{array}{l}\text { Moderately infiltration rates leading to moderately runoff } \\
\text { potential }\end{array}$ & Silty loam and loam \\
\hline C & High/moderate runoff potential because of slow infiltration rates & $\begin{array}{c}\text { Sandy loam } \\
\text { clay, silty clay and clay }\end{array}$ \\
\hline D & High runoff potential with very low infiltration rates & lay silty clay loam, sandy \\
\hline
\end{tabular}

Table 1 Soil group and corresponding soil texture

Table can be used to find the hydrologic soil groups of the study area depending on the soil type.

The high runoff potential is present in the west of the study area because this area is a mostly lies in wasteland and open land. The soil texture is clay stone or silt clay to clay.

A moderate runoff potential occurs in the south eastern part of the study area because the landforms in this region are fluctuating between undulating and plain terrain the runoff seem to high near the urban settlement.

Hydrologic condition refers to the effect of the land cover, and represents the surface conditions in the basin in relation to infiltration and runoff. The land cover that is present in figure can be used together with a map of hydrologic soil group in ERDAS model maker to match the hydrologic soil group with the land cover. Table presents the values of curve number based on the USGS classification system (A, B, C and D).

\begin{tabular}{|c|c|c|c|c|}
\hline \multicolumn{5}{|c|}{ Hydrologic Soil Group } \\
\hline Land cover/Land use & $\mathbf{A}$ & B & $\mathbf{C}$ & D \\
\hline Built up & 74 & 85 & 90 & 92 \\
\hline Cropland & 72 & 81 & 88 & 91 \\
\hline Fallow land & 77 & 86 & 91 & 94 \\
\hline Forest & 43 & 65 & 76 & 82 \\
\hline Wasteland & 77 & 86 & 91 & 94 \\
\hline Water body & 98 & 98 & 98 & 98 \\
\hline
\end{tabular}

Table 2 Runoff curve number for combinations of different land cover and hydrological soil groups

Table 2 -The Curve numbers were thus generated using the USGS land cover and Hydrologic soil group classification system (Maidment 1993). The curve number value for each hydrologic soil group and corresponding land cover class presented in Table 2. A high value of the curve number (such as 94) refers to an area that has a high runoff potential and low infiltration. A low value to the curve number (such as 43 ) indicates an area that has a low runoff potential and high infiltration. 


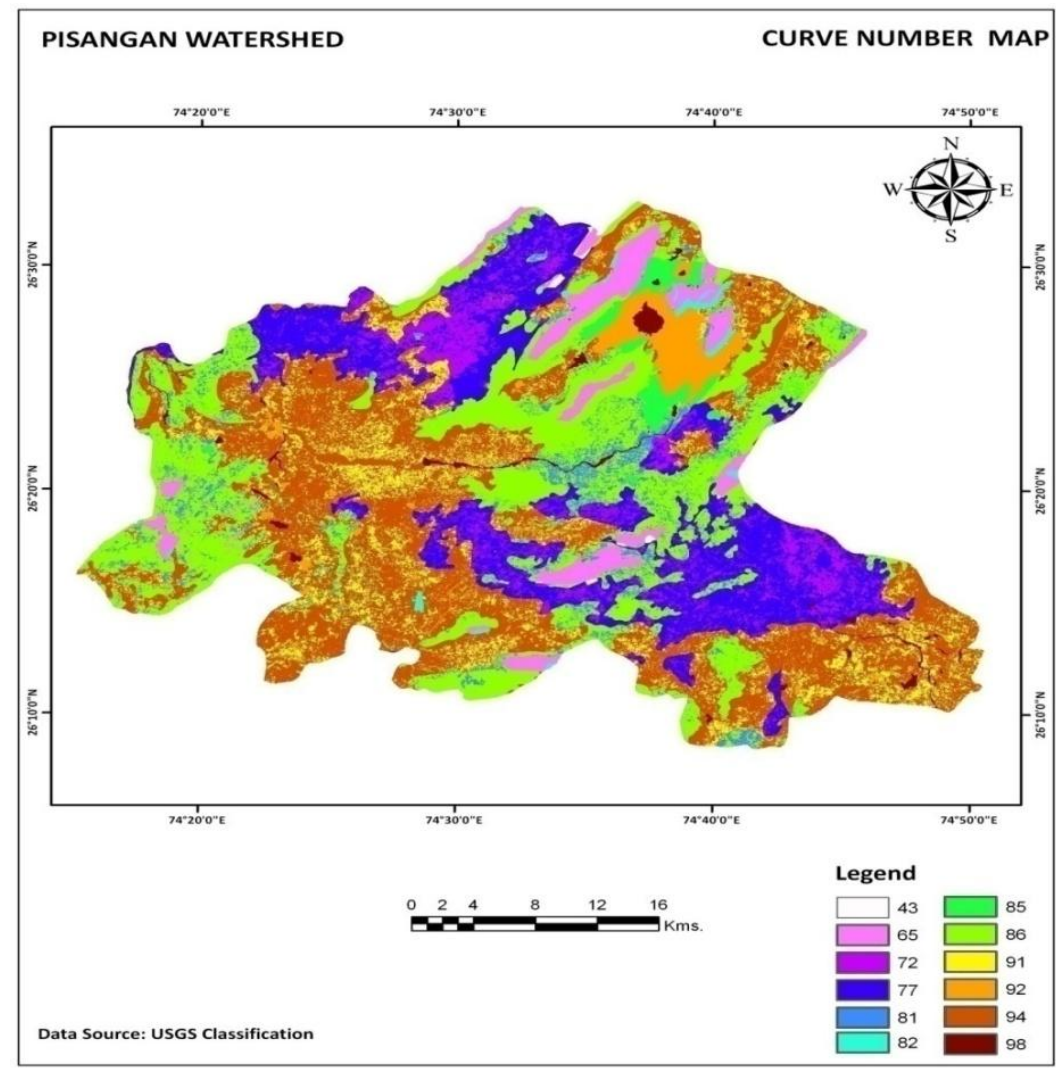

Figure 4 Curve Number Map

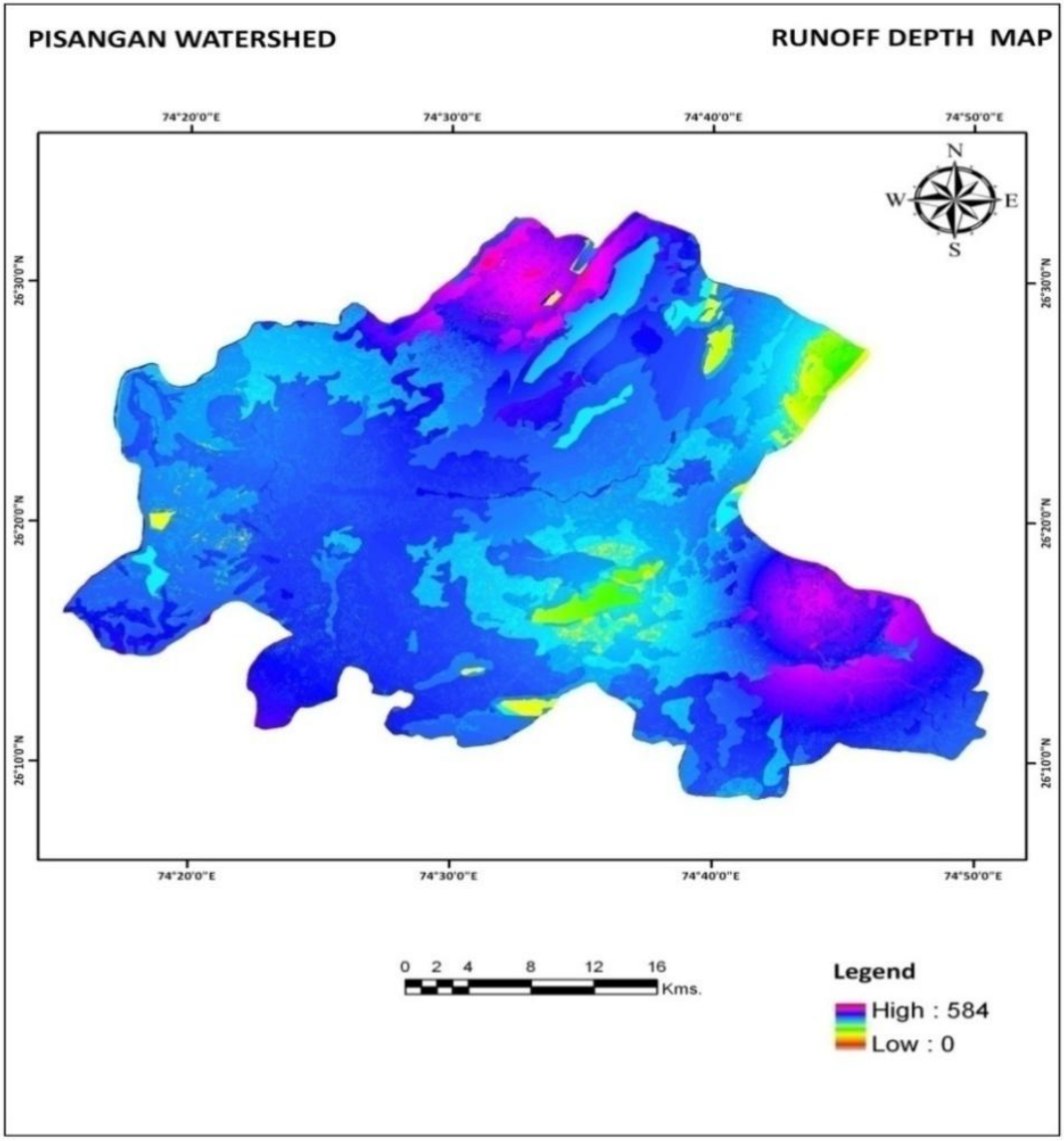

Figure 5 Runoff Depth Potential Map 


\section{Analysis Through equal weightage}

Equal Weightage Approach is assigned of relative importance which is a simple map overlay method of GIS in which all parameters are treated to be equal importance. In this study, Equal weightage approach has been adopted. Weighted Sum overlay analysis follows the same general steps of the overlay analysis described above.

Using the Weighted Sum tool, complemented by other Spatial Analyst tools, an additive overlay analysis can be implemented. The values for the input layers need to be reclassified prior to using the Weighted Sum tool. Unlike the weights in the Weighted Overlay tool, the weights assigned to the input rasters can be any value and do not need to add to a specific sum. When adding the input rasters, the
Weighted Sum tool output values are a direct result of the addition of the multiplication of each value by the weights. Unlike Weighted Overlay, the values are not rescaled back to a defined scale; therefore, it maintains the attribute resolution of the values entered in the model. Weighted Sum assumes that more favorable factors result in the higher values in the final output raster, therefore identifying these locations as being the best.Any class can also be assigned a restricted value, which means that the corresponding area is unacceptable or cannot be used. Restricted areas are excluded from the analysis. In the land-use raster, for example, unclassified area is restricted. These parameters are overlaid on one another and the resultant integrated layer is synthesized using defined criterion to derive the required solution.

\begin{tabular}{|c|c|c|c|}
\hline Raster Layer & $\begin{array}{l}\text { Influence (\%) } \\
\text { (Theme weight) }\end{array}$ & $\begin{array}{l}\text { Feature Classes } \\
\text { Or Buffer Distance }\end{array}$ & Feature Weight Class \\
\hline \multirow[t]{2}{*}{ Lineament Buffer } & 20 & Lineament Buffer & \\
\hline & & $100 \mathrm{~m}$ & 9 \\
\hline \multirow[t]{9}{*}{ Geomorphology } & 15 & Landforms & \\
\hline & & Alluvial Plain & 9 \\
\hline & & Denudational Hill & 3 \\
\hline & & Eolian Plain & 9 \\
\hline & & Habitation Mask & 1 \\
\hline & & Pediplain & 7 \\
\hline & & Piedmont Zone & 7 \\
\hline & & Structural Hills & 5 \\
\hline & & Waterbody Mask & 1 \\
\hline \multirow[t]{7}{*}{ Lithology } & 15 & Rock Type & \\
\hline & & Alluviam/Sandstone & 9 \\
\hline & & Granite/ Gneissic & 6 \\
\hline & & Habitation Mask & 1 \\
\hline & & Phyllite & 2 \\
\hline & & Quartize & 4 \\
\hline & & Waterbody Mask & 8 \\
\hline \multirow[t]{5}{*}{ Soil } & 10 & Soil Type & \\
\hline & & Loamy Sand & 3 \\
\hline & & Fine Loamy & 8 \\
\hline & & Coarse Loamy & 5 \\
\hline & & Loamy Skeletal & 6 \\
\hline
\end{tabular}




\begin{tabular}{|c|c|c|c|}
\hline & & Rock Outcrops & 5 \\
\hline & & Sandy Loamy & 3 \\
\hline \multirow[t]{5}{*}{ Slope } & 25 & Slope Structure & \\
\hline & & Gently Sloping & 7 \\
\hline & & Level to Gently Sloping & 9 \\
\hline & & Moderate Sloping & 5 \\
\hline & & Others & 3 \\
\hline \multirow[t]{6}{*}{ LULC } & 15 & Class & \\
\hline & & Agriculture & 8 \\
\hline & & Built Up & 1 \\
\hline & & Forest & 4 \\
\hline & & Wasteland & 5 \\
\hline & & Waterbody & 9 \\
\hline
\end{tabular}

Table 3 Weight Determination of Different layers

\section{Weighted Index Model}

Weighted Index Model, represent the weighting the multiple parameters. In this study of Pisangan Watershed, equal weightage concept is used for data integration in which all parameters are treated to be equal importance. All thematic layers prepared in the study of Pisangan Watershed are classified, in reference to the site suitability of Water Harvesting Structures. In this study, the most important aspect is to assess the area of high potential zones of water, through which the measures based upon the sustainable development of different parameters of surface water resources. All this is done by keeping in view that all the parameters are dependent on each other as respect to the study.

A Multi Criteria based analysis has been adopted for the identification of such areas. All the layers generated in the

ArcGIS-9.2 software are in the vector format, for Weighted Overlay Analysis the Rasterization of each physiographic unit is performed by the conversion tools in the Arc Tool Box Window. The first step of data conversion is 'Rasterization' for converting different lines and polygon coverage into raster data format.

After this, Reclassification of all the raster files is processed along with providing the scale value of each unit. All the layers are given ranking based on their influence on the study. A criterion is assigned, which shows the relationship amongst the different parameters in the same units. Further, in the Spatial Analyst Tool, Weighted Overlay Function has been processed for identification of the suitable area.

\section{Analytic Hierarchy Process (AHP)}

In this study, pairwise comparison, known as the Analytic Hierarchy Process (AHP), was used. This method was developed by Saaty (1977). The pairwise comparison method includes the comparison of each factor against every other factors in pairs (Ronad 2006). The weights of criteria in Saaty's technique are computed by applying the main eigenvector of the square reciprocal matrix of pairwise comparisons between the two factors (Drobne et al 2009).

Consistency ratio (CR): 0.0152

\begin{tabular}{llllll}
\hline & $\begin{array}{l}\text { Runoff } \\
\text { Depth }\end{array}$ & Slope & $\begin{array}{l}\text { Soil } \\
\text { texture }\end{array}$ & Drainage & $\begin{array}{l}\text { Land } \\
\text { use }\end{array}$ \\
\hline Rainfall & 1 & 2 & 3 & 4 & 5 \\
Slope & $1 / 2$ & 1 & 2 & 3 & 4 \\
Soil texture & $1 / 3$ & $1 / 2$ & 1 & 2 & 3 \\
Drainage & $1 / 5$ & $1 / 4$ & $1 / 3$ & 1 & 2 \\
Land use & $1 / 6$ & $1 / 5$ & $1 / 4$ & $1 / 2$ & 1 \\
\hline
\end{tabular}

Table 4: Different weight assign to Layers through AHP 
The International Archives of the Photogrammetry, Remote Sensing and Spatial Information Sciences, Volume XL-8, 2014 ISPRS Technical Commission VIII Symposium, 09 - 12 December 2014, Hyderabad, India

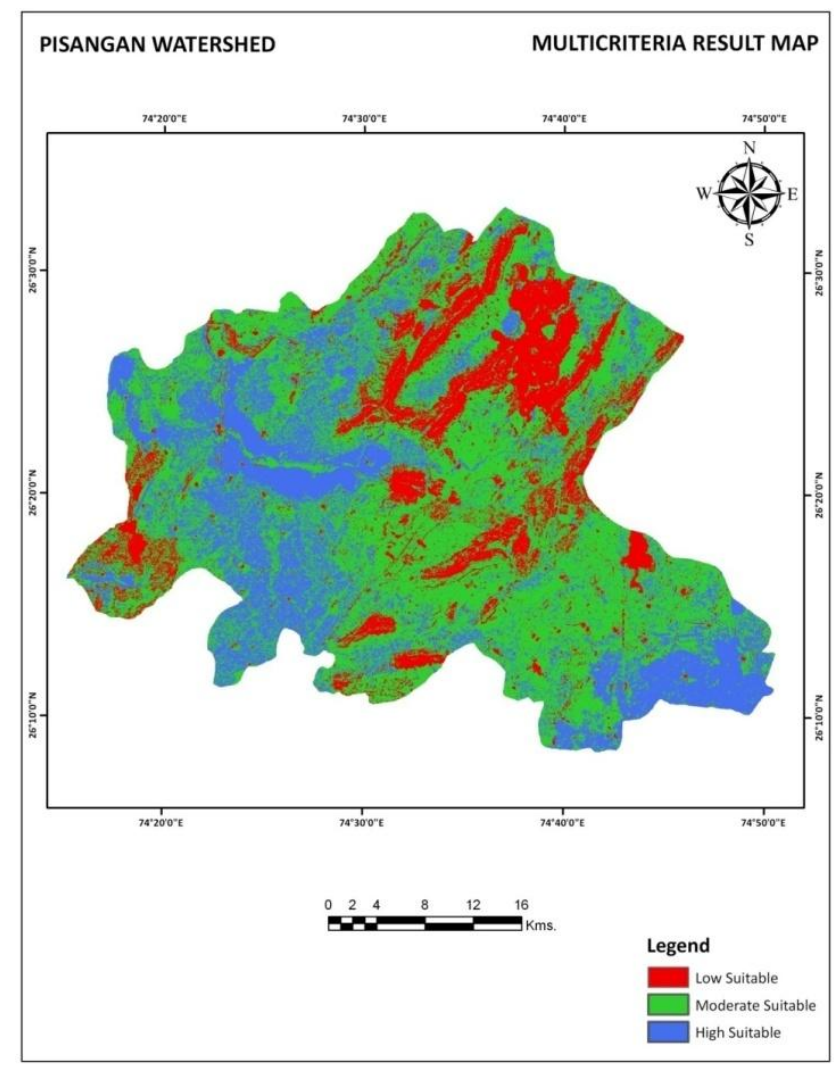

Figure 6 Multi Criteria Analysis Result Map

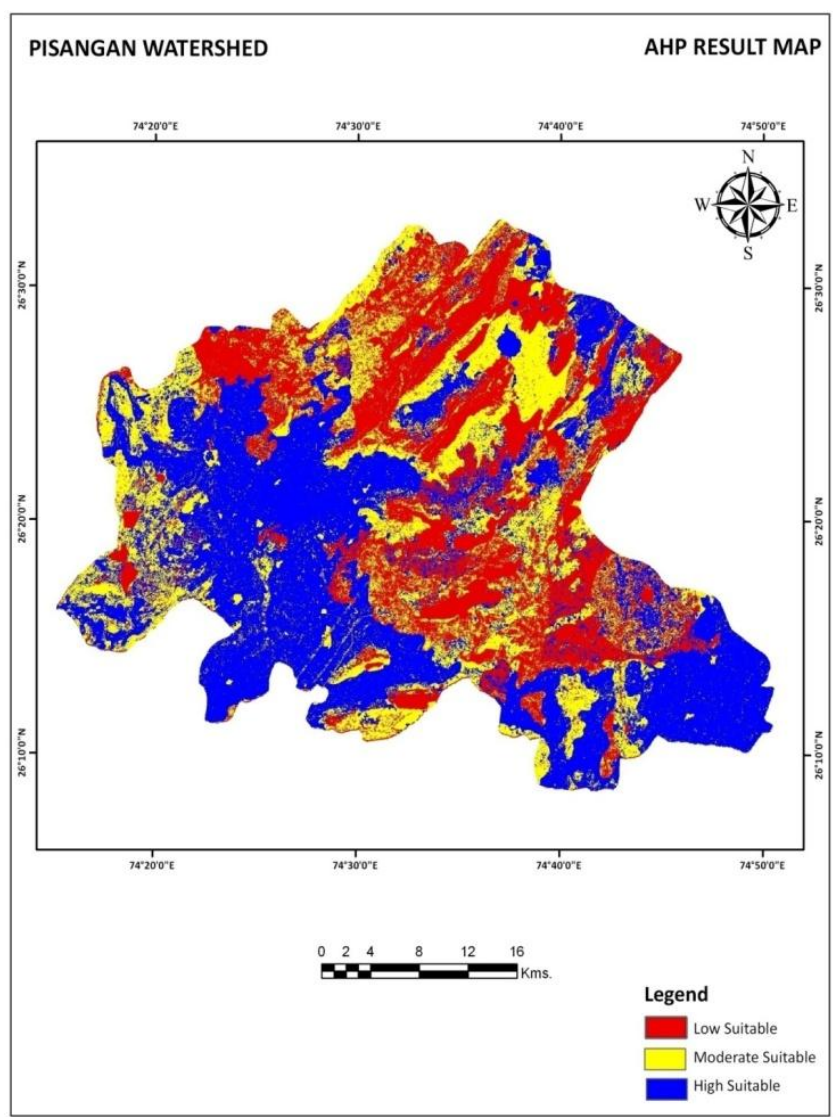

Figure 7 AHP Result Map 


\section{Results}

The multi layer integration through land use/cover slope, flow direction, drainage (buffer) road (buffer) and settlement (buffer) gave the suitability units for identifying RWH sites for insitu, ponds, rocks and dam catchments. Factor layers (maps) were incorporated in ArcMap MCE analysis, using the Weighted Overlay function in the ArcGIS analyst, finally, a final suitability map was developed that show the potential sites for different Water Harvesting Sites in study area. The suitability maps below for the different rainwater harvesting show that there are multiple areas suitable for each techniques from the weighted overlay, figures 8 show the suitability maps for location of stop dams, check dams, percolation tank, storage tank and in-situ respectively.

The AHP Result has been used to saw the rainfall runoff of the watershed; the runoff is mainly seen on the South side of the watershed and on the south east portion of the watershed. One of the cities Nasirabaad located in this region. The rainfall mainly recharges the groundwater and increase the potential of the ground water.

\begin{tabular}{|c|c|c|c|c|c|}
\hline S.No & $\begin{array}{c}\text { Types of } \\
\text { Structure }\end{array}$ & Lithology & $\begin{array}{c}\text { Land Use/ Land } \\
\text { Cover }\end{array}$ & Slope & Drainage \\
\hline 1 & Storage Tank & Sandstone/Limestone & Wasteland & Steep Slope & $2^{\text {nd }}$ or $3^{\text {rd }}$ Order Stream \\
\hline 2 & Percolation Tank & Sandstone/Quartzite & Land with Scrub & Moderate Slope & $2^{\text {nd }}, 3^{\text {rd }}$ or $4^{\text {th }}$ Order \\
Stream
\end{tabular}

Table 5 Water Resource Management Map

\section{Rain Water Harvesting Systems}

Storage tank is one of the structures for surface water storage. These structures are very useful in rain water harvesting. Storage tanks are often cylindrical in shape, perpendicular to the ground with flat bottoms and a fixed or floating roof.

In the study of Pisangan Watershed, the most suitable areas for storage tank is suggested in the areas where open and land without scrub along with sandstone and less density of lineaments are found having steep slope. Twelve sites for construction of storage tanks are suggested in the Pisangan Watershed. The suggested sites are in the areas of Govindgradh village, Kishanpura village and Hokran Bari village. These areas fulfill all the necessary conditions needed for construction of storage tanks.

Percolation tanks are the structures for recharging ground water. These are generally constructed across streams and bigger gullies in order to impound a part of the run-off water.

In the study of Pisangan Watershed, areas which are under land with scrub, moderate slope, basalt and high density of lineaments is proposed for percolation tank. Sixteen sites for construction of percolation tanks are suggested in the Pisangan Watershed. The suggested sites are in the areas of Gowaliya village and somalpur village. These areas fulfill all the necessary conditions needed for construction of percolation tanks.
Stop Dam is a masonry barriers built across the direction of water flow on shallow rivers and streams for the purpose of water harvesting for irrigation as well as for domestic and animal use. In the study of Pisangan Watershed, the areas of open degraded forest, gentle slope and $3^{\text {rd }}$ to $4^{\text {th }}$ order stream is proposed for stop dam. Thirteen sites for construction of stop dams are suggested in the Pisangan Watershed. The suggested sites are in the areas of Rampura village and Gola village. These areas fulfill all the necessary conditions needed for construction of stop dams.

Check dams are small devices constructed of rock, sediment retention fiber rolls, gravel bags, sandbags, or other proprietary product placed across a natural or manmade channel or drainage ditch. A properly designed, constructed, and maintained check dam will reduce scour and channel erosion by reducing flow velocity and encouraging sediment settlement.

In the study of Pisangan Watershed, areas having double crop, sandstone, very gentle slope and $5^{\text {th }}$ and $6^{\text {th }}$ order stream are proposed for check dams. Fifteen sites for construction of check dam are suggested in the Pisangan Watershed. The suggested sites are in the areas of Peesangan village, Amitpura village and Amangarh village. These areas fulfill all the necessary conditions needed for construction of check dams.

For Water Resource management, shown in Fig8 the Study area of Pisangan Watershed has resultant in the areas where different implementation can be done based on different area suitable for the sustainable development of Water Resources. 


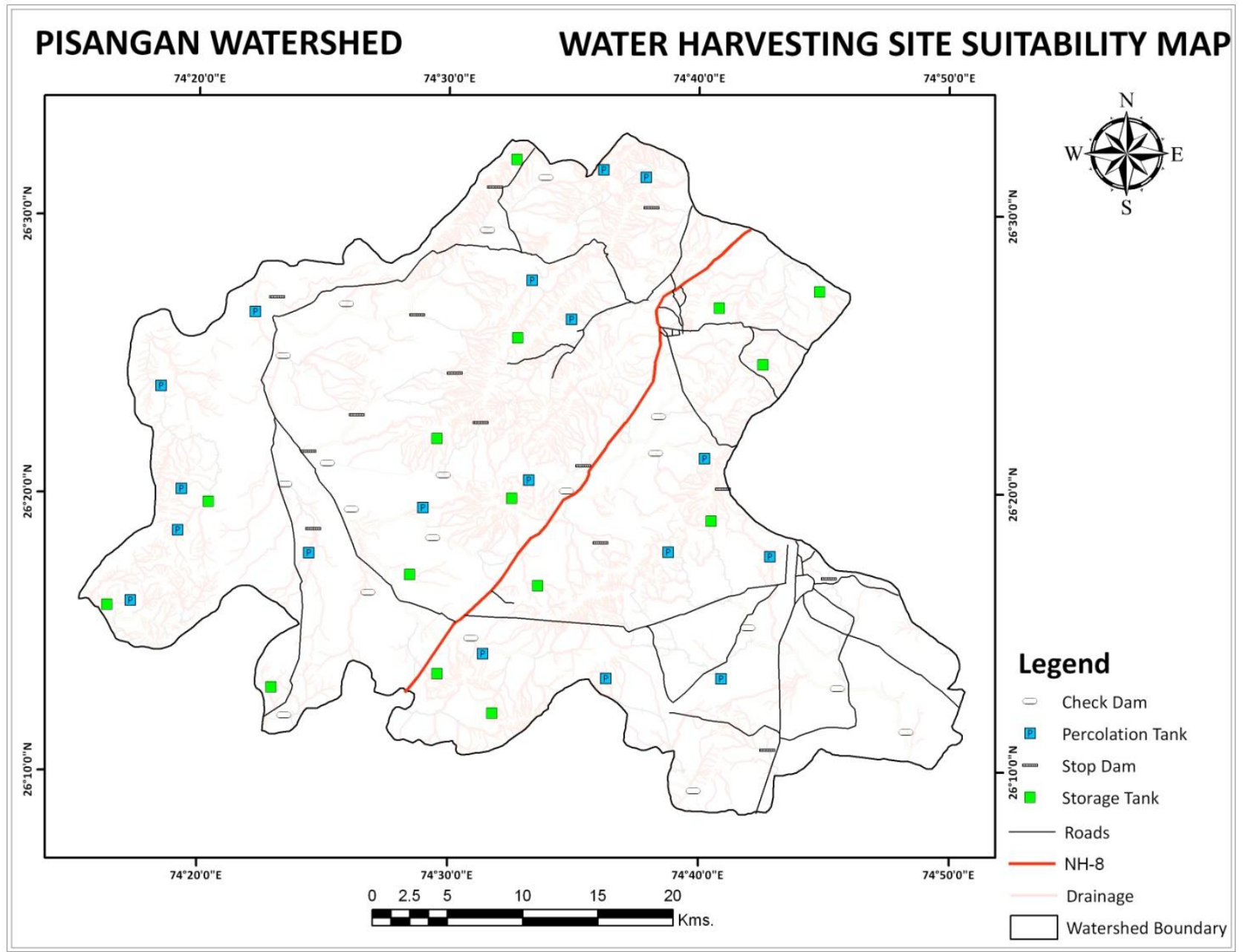

Figure 8 Water Harvesting Site Suitability Map

\section{Conclusion}

Due to rapid urbanization in the study area, demand for water Consumption has increased at an unprecedented rate. Statistics on water availability in the study area has already revealed that water table has gone down remarkably in last 2-3decades. Nevertheless, the area has sufficient potential to feed on the ever increasing demand of water if harvest and conserve properly.

Geographic information system(GIS), a spatial as well as non spatial database management system, enables us to manage a large volume of data from a variety of sources.GIS stores, retrieve, manipulate and analyze and present the data according to the user defined specification, and therefore, is an ideal tool in advanced site-selection studies.

Site selection for RWH is carried out by overlying the slope, soil, land use/land cover \& buffered stream order maps. The study area is having full scope for storage tanks, percolation tanks, stop dam and check dams. Produced map will help in the selection of the suitable location of harvesting structures and hence, help in water conservation in water depleted area. For Site Suitability for Water Resource Management approach, thematic layers such as Lithology, Geomorphology, Lineaments and Land use/Land cover features basically the physical properties of the watershed were generated from the remote sensing data and integrated with Drainage, Soil and Slope maps under GIS environment. Further, Multi Criteria Based Analysis was done to demarcate the zones of suitable surface and ground water exploitation structures and artificial recharge structures by using Equal weightage approach. Thus, integrated remote sensing and GIS can provide the appropriate platform for analysis of multi disciplinary data and sustainable development of land and water resources. Remote sensing data can especially play significant role in generation of parameters from remote areas of watershed and enable us to arrive at natural resource management solutions by adopting a holistic approach.

The soil conservation service model was applied by using average annual rainfall for the period 2000 to 2012 in Pisangan area to estimate the runoff depth. The analysis of rainfall indicates that a significant amount of annual runoff depth can be harvested. Using GIS techniques, these databases can be converted to information about land use/land cover mapping and change detection, runoff estimation, soil erosion study, site suitability analysis for rain water harvesting, watershed prioritization etc. can be effectively carried out using GIS techniques. The remote sensing technology could be used for monitoring the progress of implementation work and also assess the impact of the implementation. 


\section{References}

- Brady, N.C. (1974). The Nature and Properties of Soils. New York: MacMillan. 639 pp.

- Central Ground Water Report (2008), State Government Rajasthan.

- Chakaravarty A.K (1993), Strategies for watershed management planning using Remote sensing techniques, Journal of Indian society of Remote Sensing Vol-21, pp 87-98.

- Durbude. D.G \&Venkatesh, B(2004), Site suitability analysis for soil \& water conservation structures, Journal of Indian society of Remote Sensing Vol-32, pp- 399-405.

- $\quad$ IWMP Report of Ajmer District (2009), Soil and Water conservation Department

- Joshi .K.A,Kundal.P, (2004), water resources development action plan for sati watershed chandrapur district, Maharashtra using Remote sensing and GIS, Journal of Indian society of Remote Sensing Vol-32.

- Kumar.Girish. M, Aggrawal.K.A (2008)Delineation of potential sites for water harvesting structures using Remote Sensing and GIS, Journal of Indian society of Remote Sensing Vol-36, pp 323-334.

- Raojagdesswara P. and Rao, Suryaprakasa.B,(2004) An integrated study on ground water resources of peddagedda watershed, Journal of Indian society of Remote Sensing Vol-34.

- $\quad$ Rao. K, Singh K.D,(2006) Sustainable development of land and water resources using Remote Sensing and GIS, Journal of Indian society of Remote Sensing Vol34, pp 223-229.

- Singh. P.J, Singh.Darshdeep,(2009) Selection of suitable sites for water harvesting structures in soankhand watershed, Punjab using Remote sensing \& GIS approach - A Case Study, Journal of Indian society of Remote Sensing Vol-37.

- Sharma.K.V, Patil. S.G (2008), Application of RS Technology for Impact Assessment of watershed development programme, Journal of Indian society of Remote Sensing Vol-36

- Trivedi.R.K\& Singh, R.M (2005), A micro level approach for integrated watershed investigation development planning \& artificial recharge site selection for ground water in malani river watershed, Gondwana geological magazine,Vol-20, pp-137-146.

- Thinh N.X \& Vogel R.T (2007), Application of Analytic Hierarchy process in the multiple criteria decision analysis of retention areas for flood risk management, Environmental informatics and systems research, pp-675-682.

- http://www.physicalgeography.net/fundamentals/10ah.h tml

- $\quad$ http://support.esri.com/en/knowledgebase/GISDictionar $\mathrm{y} / \mathrm{term} /$ reclassification 